ГЛОБА

Анастасія Олександрівна anastasiia.hloba.ua@gmail.com

студентка, Київський національний університет імені Тараса Шевченка

УДК 347.431 .5

ПИТАННЯ ОДНОРІДНОСТІ ЗУСТРІЧНИХ ВИМОГ, ВИРАЖЕНИХ В РІЗНИХ ВАЛЮТАХ: ТЕОРЕТИКОПРАВОВИЙ АНАЛІЗ

\section{ISSUES OF SIMILARITY OF \\ COUNTERCLAIMS EXPRESSED IN \\ DIFFERENT CURRENCIES: THEORETICAL AND LEGAL ANALYSIS}

DOI: https://doi.org/10.37634/efp.2020.11.5
ЦЮПРИК

Володимир Ігорович volodymyrtsiupryk@gmail.com

студент, Київський національний університет імені Тараса Шевченка

HLOBA Anastasiia Oleksandrivna - student, Kyiv National University after Taras Shevchenko

TSIUPRYK Volodymyr Ihorovych - student, Kyiv National University after Taras Shevchenko

Статтю присвячено розгляду проблеми визначення змісту однорідності зустрічних вимог, виражених в іноземних валютах. Автори з'ясовують, чи можна вважати однорідними зустрічні вимоги, виражені у різних валютах, за яких умов теоретично можливо здійснити зарахування таких вимог, а також якими є законодавчі підстави, що роблять можливим здійснення такого зарахування. У ході дослідження автори приходять до висновку, щзо зустрічне зарахування однорідних вимог при їх зарахуванні в іноземній валюті законодавством Украйни чітко не встановлено. Авторами наведений підхід, відповідно до якого у випадках, коли законодавство надає право суб'єктам здійснювати розрахунок в іноземній валюті, таке зарахування є можливим. На основі дослідження вироблені пропозииї до вдосконалення законодавства задля усунення наявних прогалин і його застосування.

$* * *$

Статья посвящена проблеме определения значения и сути однородности встречных требований, выраженных в разных валютах. Авторы определяют, можно ли считать однородными встречные требования в разных валютах, при каких условиях теоретически возможно произвести зачет таких требований, а также какие есть законодательные основания, которые разрешают выполнение такого зачета. В прочессе исследования авторы приходят к выводу, что зачет встречных однородных требований, выраженных в иностранной валюте, законами Украины четко не определен. Авторами приведен подход, при котором в случаях, когда законодательство дает право субъектам выполнять расчет в иностранной валюте, такой зачет возможен. На основании исследования предложены подходы к улучшению законодательства и его применения.

$* * *$

Introduction. The work considers the problem of similarity determination of counterclaims, expressed in different currencies. Offset of similar counterclaims is one of the grounds for termination of obligation, established by the Civil Code of Ukraine. However, the Code does not consider main conditions of an offset, as well as it does not give an interpretation of "similarity" of counterclaims. Moreover the issue of similarity of counterclaims, expressed in different currencies is not examined enough by doctrine, as well as not established in legislation. That is the reason why case law has to form its own position on this issue.

The purpose of the paper is to investigate legislation, case law and doctrine in search of a uniform and complex understanding of similarity of counter claims expressed in different currencies; make theoretical and legal analysis of possibility and terms of such an offset; and make offers to improve legislation.

Results. Authors made an analysis of legislation, case law and doctrine. It showed that these sources keep to a position that counterclaims expressed in different currencies are not similar, and thus, they are not allowed to be set off. However, as a result of this work the authors found that offset of counterclaims, expressed in different currencies is neither allowed nor strictly prohibited under Ukrainian law. Case law adheres to the position that different foreign currencies do not comply with the characteristic of similarity. Authors suggest an alternative under which in case legislation entitles to use foreign currency as money, such an offset can be made.

Conclusion. Pursuant to analysis made in this work, authors came to the conclusion that theoretically under certain terms setoff of counter claims expressed in different currencies can be made. Authors also make suggestions for improvement of legislation and elimination of contradictions in law enforcement. That is why authors offer to provide in legislation the possibility of making offset of counterclaims, expressed in different currencies. The Civil Code of Ukraine is an act where these rules have to be established.

Ключові слова: зарахування зустрічних зобов'язань, однорідність вимог, іноземна валюта, розрахунки у іноземній валюті щуодо надання банківських та фінансових послуг

Ключевые слова: зачет встречных обязательств, однородность требований, иностранная валюта, расчет в иностранной валюте при предоставлении банковских и финансовых услуг

Keywords: offset of similar counterclaims, similarity of counterclaims, foreign currency, usage of foreign currency as money by banks and financial institutions 


\section{ВСТУП}

Зарахування зустрічних однорідних вимог є однією iз визначених цивільним законодавством підстав припинення зобов'язань. Цивільний кодекс визначає загальні умови здійснення такого зарахування, визначаючи лише те, що такі вимоги мають бути «однорідними», проте не розтлумачуючи суть цієї ознаки. Так, станом на сьогодні відсутнє законодавче закріплення поняття однорідності таких вимог, що значно ускладнює процес застосування такого способу припинення зобов'язання. Через це на практиці виникають спірні питання стосовно можливості здійснення такого зарахування, зокрема у випадках, коли зустрічні вимоги виражені у різних валютах.

Доктринальне дослідження питання здійснення зарахування зустрічних вимог здійснювало чимало науковців-цивілістів, серед яких I.А. Ісаєв, Р.С. Бевзенко, П. Нобель, О.В. Дзера, Н.С. Кузнецова, Т.М. Чубар та ін.

Проте питання можливості здійснення зарахування зустрічних вимог виражених в різних валютах не $\epsilon$ достатньо дослідженим української науковою спільнотою. Крім того, це питання не є врегульоване законодавством. Тому українські суди «змушені» самостійно формувати правові підходи до вирішення цього питання, які часто $є$ суперечливими.

Дослідження питання можливості застосування зарахування зустрічних вимог, виражених у різних валютах, дозволить усунути ті суперечності, що виникають через недостатню дослідженість цього правового явища.

Ці суперечності можна усунути, дослідивши такі питання:

1. Чи можна вважати однорідними зустрічні вимоги, виражені у різних валютах?

2. Якщо так, то за яких умов можливо здійснити зарахування зустрічних вимог, виражених у різних валютах?

3. Якими є законодавчі підстави, що роблять можливим здійснення такого зарахування?

МЕТА роботи - вироблення комплексного підходу стосовно розуміння однорідності вимог, виражених у різних валютах, аналіз можливості здійснення зустрічного зарахування таких вимог, визначення критеріїв здійснення такого зарахування, а також внесення пропозицій відносно вдосконалення законодавства для здійснення зустрічного зарахування.

\section{МЕТОДИ ДОСЛІДЖЕННЯ}

Методологічну основу роботи складають, нормативно-правові акти України, наукові праці, наукові матеріали періодичних видань, ресурси Internet. У ході проведення дослідження застосовуються методи аналізу, синтезу, порівняння та узагальнення.

\section{РЕЗУЛЬТАТИ}

3'ясування правової природи однорідності вимог у разі зустрічного їх зарахування є неможливим без з'ясування правової природи самого зустрічного зарахування як однієї з визначених законодавством обставин, які слугують підставою для припинення цивільно-правових та господарсько-правових зобов'язань.
Серед українського наукового товариства традиційно не існує єдиної позиції стосовно доктринального визначення зустрічного зарахування як правового явища. Р.С. Бевзенко та Т.Р. Фахретдінов дають визначення зарахування зустрічних однорідних вимог як засіб часткового виконання боржником зобов'язань у випадку його неспроможності [1]. П. Нобель вказує, що це правочин із погашення зустрічного зобов'язання за рахунок частини власного [2]. О.В. Дзера та Н.С. Кузнецова визначають зустрічне зобов'язання як таку підставу припинення зобов'язання, за якої припиняються зустрічні однорідні вимоги, строк виконання яких настав (не зазначений, визначений моментом витребування) [3].

У законодавстві України визначення поняття «зустрічне зарахування» знайшло своє відображення у положеннях Цивільного кодексу України (далі - ЦК) і Господарського кодексу (далі - ГК). Відповідно до ч. 1 ст. 601 ЦК України зобов'язання припиняється зарахуванням зустрічних однорідних вимог, строк виконання яких настав, а також вимог, строк виконання яких не встановлений або визначений моментом пред'явлення вимоги [4].

Відповідно до ч. 3 ст. 203 ГК України господарське зобов'язання припиняється зарахуванням зустрічної однорідної вимоги, строк якої настав або строк якої не зазначений чи визначений моментом витребування [5]. Це положення повністю кореспондується зі змістом ч. 1 ст. 601 ЦК України. I у ЦК і у ГК у відповідних положеннях зазначається така ознака зустрічних вимог, які можуть бути зараховані як їх «однорідність». 3 огляду на це можна зробити висновок про те, що однорідність зустрічних вимог є обов'язковою умовою для можливості їх зустрічного зарахування.

Попри встановлення такої ознаки в наведених вище статтях ЦК та ГК України визначення «однорідності» у законодавстві відсутнє. Проте ЦК України оперує поняттям «речі, визначені індивідуальними або родовими ознаками». Так, відповідно до ч. 2 ст. 184 ЦК річ $є$ визначеною родовими ознаками, якщо вона має ознаки, властиві всім речам того ж роду, та вимірюється числом, вагою, мірою. Така річ є замінною. Натомість відповідно до ч. 1 цієї ж статті річ $є$ визначеною індивідуальними ознаками, якщо вона наділена тільки їй властивими ознаками, що вирізняють іiі з-поміж інших однорідних речей, індивідуалізуючи iii. Речі, визначені індивідуальними ознаками, є незамінними [4].

Так, ЦК України розрізняє ці два поняття, а також зазначає, що речі визначені індивідуальними ознаками є замінними, на відміну від речей, визначених індивідуальними ознаками. Зважаючи на це, можемо зробити висновок, що предметом зустрічного зарахування можуть бути виключно предмети, визначені родовими ознаками. Однак цього недостатньо для тлумачення однорідності вимог у разі зустрічного зарахування.

Як зазначав науковець Ісаєв, необхідність умови однорідності вимог за їх предметом пояснюється намаганням забезпечити рівність сторін, оскільки лише 
за однорідності вимог кожна зі сторін, зберігаючи те, що вона винна іншій, потрапляє в той стан, у якому вона перебувала б у випадку реального виконання зобов'язання [7].

Верховний Суд у складі Колегії суддів Касаційного господарського суду в справі № 914/109/16 від 22.01.2020 р. визначив одним із критеріїв вимог, які можуть підлягати зарахуванню те, що вони мають бути однорідними (зараховуватися можуть вимоги про передачу речей одного роду, наприклад, грошей). У цій постанові ВС КГС вказав, що правило про однорідність вимог поширюється на їх правову природу, але не стосується підстави виникнення таких вимог. Допускається зарахування однорідних вимог, які випливають із різних підстав (різних договорів тощо) [6].

Отже, запропоновані до зарахування вимоги можуть мати різні правові підстави, що на практиці здебільшого означає різні договори [8, с. 71]. Відповідно визначальним у цьому разі $є$ предмет зустрічних зобов'язань, який має бути один і той же [9]. Отже, однорідність вимог - це однорідність предмета пред'явлених до зарахування вимог, а не підстав їх виникнення.

Оскільки законодавчо ознака «однорідності» у разі зустрічного зарахування вимог безпосередньо не визначена, судова практика «змушена» формувати власні позиції й підходи до розв'язання цього питання за допомогою вирішення конкретних випадків і узагальнення правозастосовчих підходів на рівні Верховного Суду.

Так, Касаційний господарський суд 22 січня 2020 р. прийняв постанову у справі № 914/109/16. Відповідно до обставин справи (п. 6 Постанови), відповідач (ТОВ «Яблуневий Дар») направив позивачеві (ПАТ «Дельта Банк») заяву про припинення зобов'язання зарахуванням зустрічних однорідних вимог, у якій заявив про припинення у повному обсязі зобов'язань відносно сплати відповідачем суми заборгованості за кредитом у розмірі 6300000 євро та зобов'язань відносно сплати позивачем заборгованості на загальну суму 7122150 доларів США (що за крос-курсом станом на 12.02.2015 р. складає 6300000 Євро) за договором банківського рахунку внаслідок зарахування зазначених зустрічних однорідних вимог. Тобто ТОВ намагалась здійснити зустрічне зарахування однорідних вимог через зарахування ii зобов'язання у євро за рахунок зобов'язання банку перед ТОВ, що передбачало сплату суми еквівалентної зобов'язанню ТОВ перед банком, проте в іншій іноземній валюті - у доларах США.

Суд у п. 24 своєї Постанови вказав, що встановивши, що зобов'язання сторін у цьому разі підлягають виконанню в різних валютах (євро та доларах США), суди попередніх інстанцій дійшли правомірних висновків про те, що такі вимоги не можна вважати однорідними з огляду на те, що євро та долар США (хоч i є грошовими коштами) є різними валютами, які не $\epsilon$ рівнозначними. Отже, зарахування таких зустрічних вимог не відповідає вимогам ст. 601 ЦК України. Пропоновані судові рішення встановлюють, що різні валюти неможна вважати однорідними, оскільки вони не є рівнозначними [6].
Нами не заперечується правильність прийнятих судом рішень, адже в справі № 914/3217/16 сам факт наявності спору про право свідчить про невиконання вимоги відсутності спору між сторонами щодо умов виконання зобов'язання - ясності вимог, що полягає у відсутності спору відносно характеру зобов'язання, його змісту, умов виконання, яка $є$ необхідною для можливості здійснення зустрічного зарахування відповідно до Постанови Вищого господарського суду України від 03 серпня 2016 р. у справі № 925/2220/14 [11]. Про необхідність наявності цієї ознаки також зазначено у цій же Постанові Касаційного господарського суду в справі № 914/109/16 від 22.01.2020 р. [6].

У такий спосіб суд визнав вимоги стосовно зустрічного зарахування вимог у різних іноземних валютах неоднорідними, однак фактичною підставою для прийняття такого рішення стала не лише неоднорідність цих вимог, а й наявність спору між сторонами. Питання доцільності визнання різних валют неоднорідними речами та неможливості їх взаємного зарахування попри те, що ці речі є грошима, потребує детальнішого дослідження. Передусім необхідно з'ясувати правовий статус іноземної й національної валют, і чи дійсно ці валюти $є$ різними речами настільки, щоби ними неможливо було здійснити зустрічне зарахування.

Так, у ст.192 Цивільного кодексу України, що має назву «Гроші» у ч. 1 вказано, що законним платіжним засобом, обов'язковим до приймання за номінальною вартістю на всій території України, є грошова одиниця України - гривня [4]. Водночас у ч. 2 цієї статті згадується іноземна валюта, з чого можна зробити висновок, що цей Закон також розглядає ії як гроші.

Згідно з ЦК України за своєю правовою природою гроші традиційно відносяться до замінних, рухомих, подільних речей, визначених родовими ознаками. Ця позиція законодавця послідовно виписана в усьому тексті ЦК України (див. ст.ст. 177, 343, 718 ЦК України) [12].

В юридичному значенні гроші є особливою категорією об'єктів цивільного права, оскільки виконують роль загального еквівалента, та відповідно їм властива ціла низка специфічних особливостей. На відміну від звичайних речей такого роду, зазначена властивість грошей визначається не природними властивостями та кількістю купюр, а вираженою в них грошовою сумою. Ці грошові знаки не є тим товаром, який виступає у якості грошей. Грошові знаки є лише матеріальною формою цього товару. Самим же товаром стає у цьому випадку зобов'язання. Фактично банкноти та монети є безумовним зобов'язанням Національного банку. Саме ці зобов'язання і $є$ тим товаром, який згідно з законом є грошима, вираженими у грошових знаках [13].

Отже, якщо виходити 3 розуміння того, що зміст грошей - це зобов'язання, то, відповідно, їх слід сприймати як його зовнішню форму. Так, якщо гроші - це зобов'язання, а іноземна валюта відповідно до ст.192 ЦК є грошима, а отже, зобов'язанням, то різні валюти тоді - це є зобов'язання центральних банків різних держав. Простіше кажучи, різні іноземні валюти - це $\epsilon$ різні зобов'язання зі схожою правовою природою. Відмінністю між ними є лише те, що вони мають 
різних «боржників»-центральних банків різних держав (у випадку з доларом США) чи міждержавних утворень (у випадку з євро). Водночас усі ці зобов'язання $є$ грошима, а тому мають усі ті ознаки, що характеризують гроші як суспільне явище. У такому випадку спірним $є$ питання стосовно невизнання однорідними вимог, виражених у різних валютах.

Іноземна валюта так само є зобов'язанням центрального банку країни і фактично володіє всіма тими ж ознаками, що й національна валюта. У своїй державі ця валюта знаходиться в обігу, є еквівалентною і взаємозамінною. Різниця між іноземною й національною валютою перебуває передусім у її правовому статусі, визначеному національним законодавством.

Використання іноземної валюти, на відміну від національної, є обмеженим відповідно до українського законодавства, зокрема відповідно до ч. 1 ст. 5 ЗУ «Про валюту і валютні операції». У ч. 2 ст. 5 3У «Про валюту і валютні операції» вказані виключні випадки, за яких можливе використання іноземної валюти як законного платіжного засобу на території України. Відповідно до п. 2 ч. 2 ст. 5 ЗУ таке використання іноземної валюти здійснюється за операціями банків iз надання банківських та інших фінансових послуг на підставі банківської ліцензії [14].

Також відповідно до ч. 3 цієї статті розрахунки зі сплати процентів (відсотків) за депозитами або кредитами (позиками) можуть проводитися і в іноземній валюті. Тобто відповідно до цих операцій іноземна валюта за своїми властивостями, ознаками та правовим статусом $є$ максимально наближеною до національної валюти, що дає підстави вважати ії такою ж взаємозамінною річчю як і національну валюту. На користь цього говорить і фіксований НБУ курс валют, що дозволяє вільно застосовувати ці речі як взаємозамінні одне одному, що відповідно до положень ст. 184 ЦК є однією з ознак речей одного роду. Крім того, різні іноземні валюти наділені одним правовим статусом в Україні, і стосовно надання банківських послуг вони можуть використовуватися як законний платіжний засіб, а отже, вони наділені правовим статусом необхідним для їх застосування в якості грошей.

Як було зазначено раніше, правило про однорідність вимог поширюється на їх правову природу, але не стосується підстави виникнення таких вимог. Допускається зарахування однорідних вимог, які випливають із різних підстав. Якщо розглядати гроші як зобов'язання і відповідно різні іноземні валюти як зобов'язання різних центральних банків, то виходить що ці зобов'язання мають різні підстави виникнення (рішення різних центральних банків), проте мають одну правову природу, оскільки є грошима й мають однаковий правовий статус на території України. 3 цих міркувань позиція Верховного Суду у справі № 914/109/16 від 22 січня 2020 р. стосовно відсутності ознаки однорідності у зарахуванні вимог, виражених у різних іноземних валютах, є суперечливою, враховуючи те, що в цій ситуації стороною спору був банк, що мав право на здійснення відповідних операцій в іноземних валютах згідно з положеннями ч. 2 ст. 5 3У «Про валюту і валютні операції».
На противагу цій позиції, з огляду на проведений вище аналіз, можна зробити висновок, що зобов'язання, виражені у різних валютах, є однорідними (зокрема, у випадку, якщо однією зі сторін зобов'язання $\epsilon$ банк, який відповідно до п. 2 ч. 2 ст. 5 Закону України «Про валюту і валютні операції» може здійснювати розрахунки в іноземній валюті стосовно надання банківських та фінансових послуг [14]), а лише наявність інших додаткових факторів: як, наприклад, наявність спору стосовно правовідносин, або ж зазначення у договорі можливості виконання зобов'язання у різних валютах, мають вирішальний вплив для здійснення зустрічного зарахування. Це суперечить висновку Суду стосовно того, що ці вимоги є неоднорідними, однак загалом підтверджує хід думок та аргументацію, проведену колегією суддів під час вирішення справи, оскільки визначальним фактором для прийняття цього рішення для суду стало саме те, що відсутня інша обов'язкова умова для зустрічного зарахування - це безспірність вимог. Однак відкритим залишається питання, чи допускається таке зарахування, якщо спору між сторонами не виникає.

Серед науковців стосовно питання однорідності різних іноземних валют існує й інша позиція.

Так, науковець Т.М. Чубар вважає, що якщо згідно 3 одним із договорів зобов'язання має бути виконано лише в іноземній валюті, остання виконує функцію товару, а не грошей. Отже, у разі проведення зарахування потрібно, щоб вимоги були не лише однорідними, а й одного виду. Тобто однорідні гроші, але гривня проти гривні, а не гривня проти валюти [15].

Дійсно, іноземна валюта зазвичай розглядається українським законодавцем як товар. Зокрема це проявляється у здійсненні операцій з обміну валют відповідно до норм Положення про структуру валютного ринку України, умови та порядок торгівлі іноземною валютою та банківськими металами на валютному ринку України, затвердженого Постановою Правління Національного банку України від 02.01.2019 № 1. Так, у п. 2 цього Положення зазначено, купівля іноземної валюти - це операція з купівлі іноземної валюти за гривні, а продаж іноземної валюти - це операція 3 продажу іноземної валюти за гривні [16]. Тобто в операціях з обміну валют відбувається купівля іноземної валюти за гривні і іiі продаж за гривні, як товару, про що також свідчить те, що неможливо купити одну іноземну валюту за іншу іноземну без «посередництва» національної валюти.

У цьому випадку різні іноземні валюти дійсно виступають як товари різного роду, оскільки вони, по-перше, не $є$ взаємозамінні й не виступають еквівалентом, а тому позбавленні основних ознак, що визначають їх як гроші. По-друге, вони мають різну вартість, що підтверджується затвердженим Національним банком курсом валют, а тому вони не є речами одного роду відповідно до положень ч. 2 ст. 184 ЦК, яка «вимагає» можливість «замінності» як ознаки речей одного роду.

Проте ч. 2 ст. 5 ЗУ «Про валюту і валютні операції» визначає виключні випадки, коли іноземна валюта може використовуватися для розрахунків. У цих випадках валюта не використовується як товар, оскільки товаром українське законодавство «розраховуватися» не дозволяє. Можливість використання іно- 
земної валюти для розрахунків означає те, що вона у визначених законом випадках використовується саме в якості грошей, а тому не $\epsilon$ товаром. Таке трактування цього положення також підтверджується ст. 192 ЦК, яка визначає, що іноземна валюта може використовуватися в Україні у випадках і в порядку, встановлених законом, а отже, у визначених законом випадках вона може використовуватися як гроші.

Відкритим залишається питання стосовно можливості взаємного зарахування зустрічних вимог у різних валютах, коли іноземна валюта виступає у ролі законного платіжного засобу. Кожна іноземна валюта має офіційний курс відносно гривні, визначений Національним банком України. Вартість кожної іноземної валюти відносно одна одної може розрахуватися за допомогою «посередництва» гривні й в такий спосіб визначити вартість однієї іноземної валюти до іншої, що офіційно встановлена в Україні. Таке перерахування двох валют за допомогою їх вартості відносно третьої валюти називається крос-курсом. Відповідно за крос-курсом банківська або інша фінансова установа, що має право на здійснення подібних операцій відповідно до законодавства України, може здійснити перерахунок однієї іноземної валюти в іншу, а тому на рівні законодавства за певних обставин, здійснення зустрічного зарахування однорідних вимог у різній іноземній валюті є цілком можливим.

3 огляду на це можна зробити висновок, що у схожій ситуації 3 тією, що мала місце у справі № 914/109/16 від 22 січня 2020 р., у разі відсутності спору й наявності волі сторін стосовно здійснення такого зарахування, згідно з положеннями чинного законодавства здійснити таке зарахування цілком можливо, проте судова практика у цій ситуації вказує на протилежне, аргументуючи свої рішення тим, що різні іноземні валюти за своїми ознаками не є однорідними.

У цій справі відповідно до закону й за одним і за іншим договором (в обох випадках) іноземні валюти згідно з вищевказаними положеннями за своєю правовою природою були грошима, що суд визнав і зазначив про це у своєму рішенні (у п. 24 Постанови вказано: «... євро та долар США (хоч і є грошовими коштами) $є$ різними валютами, які не $є$ рівнозначними...») [6]. Попри це Суд визнав різні валюти такими, що не є однорідними, зазначивши водночас основною ознакою ї неоднорідності різну вартість одиниці кожної з валют, попри те, що існує офіційний курс НБУ, який повністю дає змогу еквівалентно розрахувати загальну вартість суми зустрічної вимоги з урахуванням курсової різниці за допомогою крос-курсу, про що було зазначено раніше.

На нашу думку, у цьому разі Суд ухвалив рішення, що певним способом може обмежити встановлені Цивільним кодексом і валютним законодавством права учасників цивільних правовідносин на здійснення зустрічного зарахування однорідних вимог різними валютами там, де законодавство таких обмежень не містить. Оскільки позиції суду касаційної інстанції враховуються судами нижчих інстанцій у разі прийняття ними рішень, застосування такого обмежувального тлумачення ознаки «однорідності» й надалі створюватиме прецеденти, які обмежуватимуть учасників цивільних правовідносин у застосуванні такого зручного механізму виконання зобов'язань.

Проте можливість здійснення зустрічного зарахування вимог у різних іноземних валютах є дуже обмеженою через обмеженість використання іноземної валюти в якості грошей на території України. Так, іноземна валюта може використовуватися для розрахунків в Україні лише у випадках, прямо передбачених ч. 2 ст. 5 ЗУ «Про валюту і валютні операції» й цей перелік є вичерпним. Отже, лише у випадках, визначених цим приписом, можна здійснити зустрічне зарахування в іноземних валютах, оскільки лише тоді іноземна валюта виступає в якості грошей.

Для можливості здійснення такого зарахування необхідною є також наявність визнаного державою права одного з учасників цивільних правовідносин, що мають стосунок до такого зарахування (тобто $є$ кредитором і боржником за різними зобов'язаннями відносно іншого учасника, що також $є$ кредитором i боржником стосовно першого) на здійснення валютних операцій з обміну валют (зокрема за крос-курсом). Так, відповідно до ч. 1 ст. 9 ЗУ «Про валюту і валютні операції» банки надають банківські та інші фінансові послуги, якщо вони є валютними операціями, на підставі банківської ліцензії. Відповідно до ч. 1 ст. 47 ЗУ «Про банки і банківську діяльність» банк має право надавати банківські та інші фінансові послуги (крім послуг у сфері страхування) як у національній, так і в іноземній валюті [17]. Відповідно до ч. 2 ст. 9 ЗУ «Про валюту і валютні операції» небанківські фінансові установи здійснюють валютні операції на підставі ліцензії Національного банку України на здійснення валютних операцій [14].

Тобто відповідно до положень українського законодавства здійснити зустрічне зарахування вимог, виражених у різних валютах, теоретично можливо лише, якщо один із «боржників-кредиторів» за вимогами, які підлягають зарахуванню, має банківську ліцензію чи ліцензію Національного банку України на здійснення валютних операцій (у разі, якщо він не є банківською установою).

\section{ВИСНОВКИ}

Отже, на нашу думку зустрічне зарахування однорідних вимог під час їх зарахування в іноземній валюті законодавством України чітко не встановлено, проте й не заборонено. Судова практика останніх років, зокрема Великої палати Верховного Суду та Касаційного господарського суду у своїх судових рішеннях дотримується позиції, що різні валюти не відповідають ознаці «однорідності», визначеної законодавством, попри те, що вони є грошима. Деякі науковці поділяють позиції Суду, вказуючи на те, що іноземна валюта - це товар, а отже різні іноземні валюти різні товари, а тому не можуть бути зустрічно зарахованими.

Ми не поділяємо цієї позиції, оскільки, по-перше, неможна вважати іноземну валюту товаром у всіх випадках, бо ч. 2 ст. 5 ЗУ «Про валюту і валютні операції» визначає випадки, коли можна здійснювати розрахунок в іноземній валюті, що визначає останню, як гроші, i, як наслідок, річ, що має всі ознаки грошей, зокрема, еквівалентність і взаємозамінність, а тому не 
$\epsilon$ товаром у визначених законом випадках. По-друге, за своєю правовою природою різні іноземні валюти це зобов'язання центральних банків різних держав, що відповідно до наукової доктрини, підтвердженої судовою практикою, визначає теоретичну можливість їх зарахування, оскільки допускається зарахування однорідних вимог, які випливають із різних зобов'язань, що у цьому разі має здійснюватися з обмеженнями, визначеними валютним законодавством. По-третє, існує офіційний курс НБУ, що чітко дозволяє за крос-курсом встановити еквівалентну вартість однієї валюти до іншої й чітко встановити їх вартісне співвідношення між собою. Тому у цьому разі різна вартість одиниці валюти чи інші зовнішні ознаки, що відрізняють їх між собою, як підстава визнання різних іноземних валют, такими, що не можуть бути зустрічно зараховані, $є$ сумнівною.

Загалом можна виокремити такі умови, за яких теоретично можливим є здійснення зустрічного зарахування однорідних вимог, виражених у різних (іноземних) валютах:

- наявність волевиявлення сторін щодо здійснення зарахування у різних іноземних валютах чи наявність положень у договорах, за якими виникли зобов'язання, стосовно можливості їх виконання в іншій валюті (тій, за якою виникла можливість здійснити зустрічне зарахування);

- таке зарахування не суперечить валютному законодавству (тобто здійснюється відносно тих зобов'язань, у яких передбачена можливість розрахунку в іноземній валюті);

- якщо один із «боржників-кредиторів» за вимогами, які підлягають зарахуванню, має банківську ліцензію чи ліцензію Національного банку України на здійснення валютних операцій;

- виконуються інші вимоги, що є загальними для здійснення зустрічного зарахування однорідних вимог (такі вимоги визначені, зокрема, у п. 19 Постанови Касаційного господарського суду у справі № 914/109/16 від 22.01.2020 р.).

Дійсно, це питання $є$ законодавчо не врегульованим, у чому, з огляду на судову практику й певні теоретико-правові питання до неї, є потреба. Тому для усунення розбіжностей у судовій практиці й запобіганню необгрунтованому обмеженню прав учасників цивільних правовідносин пропонуємо законодавчо визначити поняття «однорідності» та визначити умови, за яких можливе таке зарахування у ст. 601 ЦК. Також пропонуємо закріпити у ст. 601 ЦК таке положення: «Зарахування зустрічних вимог щодо зобов’язань, виконання яких передбачене у різних валютах, здійснюється лише за взаємною згодою сторін у випадках і в порядку, встановлених законодавством України».

Водночас на рівні закону необхідно встановити ви-моги, за яких можливе здійснення такого зарахування. Зокрема ними можуть бути вимоги, визначені вище стосовно теоретичної можливості здійснення зарахування зустрічних вимог. Якщо ж закріплення цих положень суперечить валютній політиці держави, то необхідно на законодавчому рівні визначити неможливість здійснення такого зарахування. У будь-якому разі для розв'язання проблем, що виникають навколо предмету дослідження цієї статті необхідно визначити можливість чи неможливість здійснення зарахування зустрічних вимог у різних валютах на законодавчому рівні для того, щоб уникнути розбіжностей у тлумаченні положень законодавства для здійснення зарахування зустрічних вимог, а також уникнути неоднаковості судової практики під час вирішення подібних спорів судами різних інстанцій.

\section{Список використаних джерел}

1. Бевзенко Р.С., Фахретдинов Т.Р. Зачет в гражданском праве: опыт исследования теоретической конструкции и обобщения судебной практики. Москва: Статут, 2006. 172 с.

2. Нобель П. Швейцарское финансовое право и международные стандарты / пер. с англ. В. Румынский и др. Москва: Волтерс Клувер, 2008. 1095 с.

3. Цивільне право України: Особлива частина: в 2 т. / за ред. О.В. Дзери, Н.С. Кузнецової. Київ: Юрінком Інтер, 2010. Т.1. $1176 \mathrm{c}$.

4. Цивільний кодекс України: Закон України від 16.01.2003 р. №435-IV. Дата оновлення: 16.10.2020. URL: https://zakon.rada.gov.ua/laws/show/435-15\#Text (дата звернення: 09.11.2020).

5. Господарський кодекс України: Закон України від 16.01.2003 р. №435-IV. Дата оновлення: 16.10.2020. URL: https://zakon.rada.gov.ua/laws/show/436-15\#Text (дата звернення: 09.11.2020).

6. Постанова Верховного Суду у складі Колегії суддів Касаційного господарського суду від 22.01.2020 р., судова справа № 914/109/16 URL: http://reyestr.court.gov.ua/Review/87129073 (дата звернення: 09.11.2020).

7. Исаев И.А. О сущности и формах зачета. URL: https://www.lawmix.ru/comm/1795

8. Цивільний кодекс України: Науково-практичний коментар: у 2 т. / за ред. Я.М. Шевченко. Київ: Видавничий дім «Ін Юре», 2004. Т. 2.896 с.

9. Исаев И. Зачет в судебной практике. Право и экономика. 2004. № 9. С. 83-86.

10. Постанова Великої Палати Верховного Суду від 30 жовтня 2018 р., судова справа №914/3217/16. URL: http://reyestr.court.gov.ua/Review/78112035 (дата звернення: 09.11.2020).

11. Постанова Вищого господарського суду України від 03 серпня 2016 р., судова справа №925/2220/14. URL: http://www.reyestr.court.gov.ua/Review/59544968 (дата звернення: 09.11.2020).

12. Посполітак В.В. До приватно-правового регулювання грошей за законодавством України. Наукові записки. Том 64. Юридичні науки. 2007. С. 85-89.

13. Карагусов Ф.С. Ценные бумаги и деньги в системе обьектов гражданских прав: учебн. пособ. Алматы: Научноиздательский центр КОУ, 2009. 232 с.

14. Про валюту і валютні операції: Закон України від 21.06.2018 року № 2473-VIII. Дата оновлення: 28.04.2020. URL: https://zakon.rada.gov.ua/laws/show/2473-19\#Tеxt (дата звернення: 09.11.2020).

15. Чубар Т М. Поняття та загальнотеоретичні умови застосування зарахування зустрічних однорідних вимог. Часопис Київського університету права. 2007. № 2. С. 167-172.

16. Положення про структуру валютного ринку України, умови та порядок торгівлі іноземною валютою та банківськими металами на валютному ринку України: затв. постановою Правління Національного банку України від 02.01.2019 № 1. Дата оновлення: 01.08.2020. URL: https://zakon.rada.gov.ua/laws/show/v0001500-19\#Text (дата звернення: 09.11.2020).

17. Про банки і банківську діяльність: Закон України від 07.12.2000 p. № 2121-III. Дата оновлення: 03.07.2020. URL: https://zakon.rada.gov.ua/laws/show/2121-14\#Text (дата 
звернення: 09.11.2020).

\section{References}

1. Bevzenko R.S., Fahretdinov T.R. Offset in civil law: research experience of theoretical construction and summary of case law. Moscow: Statut, 2006. 172 p. (in Russian).

2. Nobel P. Swizz financial law and international standards / transl. from eng. V. Rumynskyi. Moscow: NORMA, 2008. 1095 p. (in Russian).

3. Ukrainian Civil law: special part: in 2 vol. / ed. O.V. Dzera, N.S. Kuznetsova. Kyiv: Yurinkom Inter, 2010. Vol. 1. 1176 p. (in Ukrainian).

4. The Civil Code of Ukraine: Legal Act of Ukraine dated 16.01.2003 № 435-IV. URL: https://zakon.rada.gov.ua/ laws/show/435-15\#Text (Last accessed: 09.11.2020).

5. The Commercial Code of Ukraine: Legal Act of Ukraine dated 16.01.2003 № 435-IV. URL: https://zakon.rada.gov.ua/laws/show/436-15\#Text (Last accessed: 09.11.2020). (in Ukrainian).

6. Case № 914/109/16: Resolution of the Supreme Court in the composition of the Board of Judges of the Commercial Court of Cassation, 22.01.2020. URL: http://reyestr.court.gov.ua/Review/87129073 (Last accessed: 09.11.2020). (in Ukrainian).

7. Isaev I.A. Meaning and forms of offset. URL: https://www.lawmix.ru/comm/1795 (Last accessed: 09.11.2020). (in Russian).

8. The Civil Code of Ukraine: Scientific and practical commentary: in 2 books / ed. Y.M. Shevchenko. Kyiv: Edit. house "In Jure", 2004. Book 2. 896 p. (in Ukrainian).

9. Isaev I.A. Offset in case law. Law and economics. 2004. № 9. pp. 83-86. (in Russian).
10. Case № 914/3217/16: Resolution of the Grand Chamber of the Supreme Court, 30.10.2018. URL: http://reyestr.court.gov.ua/Review/78112035 (Last accessed: 09.11.2020). (in Ukrainian).

11. Case № 925/2220/14: Resolution of the Supreme Economic Court of Ukraine, 03.08.2016. URL: http://www.reyestr.court.gov.ua/Review/59544968 (Last accessed: 09.11.2020). (in Ukrainian).

12. Pospolitak V.V. Private law regulation of money under Ukrainian law. Scientific commentaries. Vol. 64. Law science. 2007. pp. 85-89. (in Ukrainian).

13. Karagusov F.S. Financial credit instruments and money in civil rights system of objects: tutorial. Alma-Ata: KOU Research and Publishing Center, 2009. 232 p. (in Russian).

14. On currency and monetary operations: Legal Act of Ukraine dated 21.06.2018 № 2473-VIII. URL: https://zakon.rada.gov.ua/laws/show/2473-19\#Text (Last accessed: 09.11.2020). (in Ukrainian).

15. Chubar T.M. Concept and general theoretical terms of offset of similar counterclaims. Chasopys Kyivskoho Universytetu Prava. 2007. № 2. pp. 167-172. (in Ukrainian).

16. Regulations on the structure of the foreign exchange market of Ukraine, conditions and procedure for trading in foreign currency and bank metals on the foreign exchange market of Ukraine: approved by Resolution of the Board of the National Bank of Ukraine dated 02.01.2019 № 1. URL: https://zakon.rada.gov.ua/laws/show/v0001500-19\#Text (Last accessed: 09.11.2020). (in Ukrainian).

17. On banks and banking: Legal Act of Ukraine dated 07.12.2000 № 2121-III. URL: https://zakon.rada.gov.ua/laws/ show/2121-14\#Text (Last accessed: 09.11.2020). (in Ukrainian). 